\title{
PELATIHAN DUKUNGAN SOSIAL UNTUK MENINGKATKAN OPTIMISME DAN KEMANDIRIAN PENYINTAS LAHAR DINGIN MERAPI YOGYAKARTA
}

\section{THE EFFECT OF SOCIAL SUPPORT TRAINING IN ENHANCHING SELF RELIANCE AND OPTIMISM AMONG MERAPI'S COLD LAVA SURVIVORS IN YOGYAKARTA}

\author{
Nuristighfari Masri Khaerani \\ Mustadin \\ Sara Palila \\ Program Studi Psikologi Fakultas IImu Sosial dan Humaniora \\ Universitas Islam Negeri Sunan Kalijaga Yogyakarta \\ Email: nuristighfari.mk@gmail.com
}

\begin{abstract}
This study intends to investigate the effect of social support training in increasing self reliance and optimism among merapi's cold lava survivor. The hypothesis is social support training can improve the self reliance and optimism among merapi's cold lava survivors. Pretest-postest group design was used, with ten participants were divided into experiment group. Data were collected using the self reliance scale by Masrun et all, and optimism scale by Seligman. The result showed that social support training cause significant increase on self reliance but did'n cause significant increase on optimism among merapi,s cold lava survivors.
\end{abstract}

Keywords: Social Support, Self Reliance, Optimism, Merapi's Cold Lava Survivor

\section{ABSTRAK}

Penelitian ini bertujuan untuk mengetahui pengaruh pelatihan dukungan sosial dalam meningkatkan optimisme dan kemandirian pada penyintas lahar dingin erupsi Merapi. Desain eksperimen adalah pretestpostest group design dengan 10 partisipan. Data diperoleh dari skala optimisme Seligman dan skala kemandirian Masrun dkk. Hasil penelitian menunjukkan bahwa pelatihan dukungan sosial berpengaruh positif pada kemandirian namun tidak berpengaruh pada optimisme pada pinyintas lahar dingin erupsi merapi.

Kata kunci: Dukungan Sosial, Kemandirian, Optimisme, Penyintas Lahar Dingin Erupsi Merapi 
Erupsi Merapi pada tahun 2010 merupakan erupsi terbesar yang terjadi dibandingkan dengan erupsi pada lima kejadian sebelumnya, yaitu pada tahun 1994, 1997, 1998, 2001 dan 2006. Berdasarkan data Pusdalops BNPB (Badan Nasional Penanggulangan Bencana) per tanggal 12 Desember 2010, bencana erupsi Gunung Merapi ini telah menimbulkan korban jiwa sebanyak 277 orang meninggal di wilayah D.I. Yogyakarta dan 109 orang meninggal di wilayah Jawa Tengah (BAPPENAS, 2011).

Dampak dari erupsi Merapi tidak hanya dirasakan pada saat erupsi terjadi, tapi juga pascaerupsi yang dikenal dengan bencana lahar dingin. Jumlah material yang dimuntahkan oleh Merapi sebanyak 140 juta meter kubik dan diperkirakan 90 juta meter kubiknya mengancam daerah sekitarnya dalam bentuk banjir lahar dingin (Kompas, 2011).

Data lainnya menunjukkan jumlah korban akibat banjir lahar dingin hingga 19 Januari 2011 sebanyak 4111 jiwa dari jumlah total pengungsi. Korban terbagi dalam 13 titik pengungsian di empat kecamatan di Kabupaten Magelang, yaitu (1) di lima titik Kecamatan Muntilan sebanyak 1786 jiwa, (2) empat titik di Kecamatan Salam sebanyak 1425 jiwa, (3) satu titik di Kecamatan Mungkid sebanyak 565 jiwa, dan (4) tiga titik di Kecamatan Srumbung sebanyak 335 jiwa (Jalin Merapi, 2011).

Jumlah total rumah yang terkena banjir lahar dingin di Kabupaten
Magelang mencapai 299 rumah. Jumlah tersebut terbagi di empat kecamatan, yaitu (1) Kecamatan Muntilan sebanyak 49 rumah, 17 rumah hanyut dan 32 rumah rusak, (2) Kecamatan Salam sebanyak 187 rumah, 65 rumah hanyut dan 122 rumah rusak, (3) Kecamatan Mungkid sebanyak 57 rumah, 5 rumah hanyut dan 52 rumah rusak, dan (4) Kecamatan Ngluwar total enam rumah rusak berat (Jalin Merapi, 2011). Kabupaten Magelang menjadi daerah yang paling rawan oleh lahar dingin Merapi (Antara News, 2011).

Korban lahar dingin di Kabupaten Magelang mendapatkan tempat pengungsian yang tersebar di berbagai titik lokasi pengungsian. Tempat pengungsian ini disediakan oleh pemerintah dan pihak swasta yang disebut dengan Hunian Sementara (Huntara). Selanjutnya lokasi tempat penelitian ini dilakukan, disebutkan sebagai Huntara $X$.

Para korban bencana lahar dingin Merapi sebagian besar mengalami keresahan. Menurut salah satu korban menyebutkan bahwa penyebab keresahan yang utama adalah adanya ketidakpastian sampai kapan mereka akan tinggal di tempat pengungsian. Mereka juga khawatir jika saat relokasi nanti, mereka tidak lagi tinggal satu tempat dengan tetangga yang senasib lainnya. Keresahan lain yang dialami adalah besarnya tempat relokasi yang tidak seluas lahan mereka dahulu sehingga mereka tidak bisa memelihara ternak lagi (wawancara, 5 Mei 2012). 
Ketidakpastian relokasi paska Huntara membawa serangkaian kondisi yang tidak menguntungkan bagi mereka. Tokoh atau orang yang dianggap sebagai koordinator di Huntara tersebut telah mencoba menghubungi pemerintah setempat dalam rangka mendapatkan kepastian mengenai tempat relokasi. Namun sayangnya, pemerintah belum dapat memberikan jawaban pasti. Pemerintah setempat masih terkendala persoalan pembebasan lahan dan sulitnya menyediakan lahan seluas yang dibutuhkan. Ketidakjelasan ini membuat mereka merasa gamang dalam membangun kembali kehidupan di masa depan. Wawancara kepada salah seorang warga mengatakan: "Kalau kondisi seperti ini ya bingung, nggak jelas, kebutuhan terus berjalan tapi mau apa ke depan masih belum tahu. Pemerintahnya nggak bisa njamin, jadi aras-arasen .. katanya suruh pindah tapi di mana dapat berapa luasnya tidak tahu .. (wawancara, 5 Mei 2012).

\section{Harapan cepatnya mengetahui} tempat relokasi serta harapan mereka akan memperoleh rumah dengan luas tanah sesuai dengan miliknya dulu yang terkena lahar dingin, tergantikan dengan pesimisme bahwa semua itu tidak akan terwujud. Menurut hasil wawancara dengan salah satu korban, kabar yang beredar menyebutkan bahwa mereka akan mendapat rumah sederhana dengan tanah yang terbatas sehingga tidak lagi dapat melanjutkan usaha ternak seperti selama ini mereka lakukan (wawancara, 5 Mei 2012).
Pesimisme, menurut Carver dan Scheier (2001), adalah ketika individu merasa bahwa masa depannya akan buruk. Pesimisme melibatkan aspek harapan akan masa depan, di mana harapan tersebut adalah negatif. Harapan tersebut melibatkan rasa kepercayaan diri bahwa ia mampu mencapai tujuan hidupnya. Pada kenyataannya, harapan yang dimiliki oleh para individu yang pesimis adalah harapan negatif yang bemakna bahwa individu tidak memiliki kepercayaan diri atau merasa ragu terhadap masa depannya. Keraguan tersebut dapat merusak energi individu dalam melakukan upaya nyata untuk meraih apa yang ia cita-citakan.

Peristiwa hidup yang diakibatkan dari faktor lingkungan seperti bencana alam dapat mengganggu keseimbangan hidup seseorang. Individu yang pesimis merasa bahwa dirinya tidak memiliki sumber bantuan yang berhubungan dengan rendahnya kepercayaan diri (Buchanan \& Seligman, dalam Gillham, Shatte, Reivich, \& Seligman, 2001).

Pesimisme sangat merugikan individu. Sebaliknya, optimisme memiliki serangkaian keuntungan bagi kehidupan. Penelitian yang dilakukan oleh Scheier dan Carver (Gillham, Shatte, Reivich, \& Seligman, 2001) menunjukkan bahwa individu yang optimis kecil kemungkinan mengalami depresi dan gangguan fisik, serta memiliki cara-cara yang adaptif dan efektif dalam menghadapi permasalahan hidupnya. Buchanan dan Seligman (Gillham, Shatte, Reivich, \& Seligman, 
2001) juga mengemukakan bahwa optimisme erat kaitannya dengan tingginya motivasi, prestasi, kesehatan fisik yang baik, dan kecil kemungkinan mengalami depresi.

Optimisme sangat diperlukan bagi semua individu. Bagi masyarakat korban lahar dingin Merapi yang tinggal di Huntara X, optimisme akan membuat mereka memiliki kepercayaan diri untuk mampu bangkit dan kembali membangun kehidupannya lebih baik dari sebelum terjadinya bencana. Optimisme juga akan membuat mereka lebih sehat dan memiliki cara yang adaptif serta efektif dalam menghadapi setiap permasalahan hidupnya.

Optimisme sangat erat kaitannya dengan kemandirian. Individu yang optimis memiliki motivasi yang tinggi dalam meraih tujuannya. Optimisme merupakan penggerak bagi individu untuk melakukan upaya nyata bagi terwujudnya tujuan hidup. Pada individu yang optimis, segala upaya yang dilakukannya tidak ditentukan oleh pihak atau orang lain maupun situasi lingkungan sehingga dengan kata lain ia akan menjadi mandiri (Carver \& Scheier, 2001).

Kemandirian, menurut Agnyal (Wolman, 1973), merupakan tendensi untuk mencapai sesuatu, mengatasi sesuatu, bertindak efektif terhadap lingkungannya, dan merencanakan serta mewujudkan harapan-harapannya. Hetherington (Spencer \& Kass, 1970) mengemukakan bahwa kemampuan untuk mengambil inisiatif, kemampuan mengatasi masalah, penuh ketekunan, serta memperoleh kepuasan dari usahanya sebagai perwujudan dari perilaku mandiri.

Serangkaian studi menemukan bahwa kemandirian memiliki korelasi positif dengan kebahagiaan (Ryan \& Deci, dalam Sheikholeslami \& ArabMoghaddam, 2010). Sebaliknya kemandirian memiliki korelasi negatif dengan kecemasan, depresi, symptom somatic, dan disfungsi sosial (Sheikholeslami \& Arab-Moghaddam, 2010).

Kemandirian menjadi permasalahan yang cukup rumit bagi banyak korban bencana alam. Kehilangan keluarga, tempat tinggal, dan sumber penghasilan membuat masyarakat lain tumbuh perasaan empatinya sehingga mengulurkan bantuan kepada korban. Kondisi ini tentu menguntungkan bagi para korban. Di sisi yang lain, sifat bantuan yang cenderung instan dan tidak terkoodinasi dengan baik membuat sesaat ketika terjadi bencana, bantuan datang membanjir, namun terputus begitu saja di saat euforianya sudah selesai. Sifat bantuan yang demikian memiliki risiko terhadap kemandirian yang sesungguhnya sangat diperlukan untuk bangkit dari keterpurukkan justru menjadi menurun. Hasil wawancara (5 Mei 2012) menunjukkan bahwa banyak warga yang berharap akan adanya bantuan terutama berkaitan dengan pemenuhan kebutuhan fisik yang sesungguhnya dapat dipenuhinya secara mandiri apabila mereka berusaha. 
Intervensi psikologis dinilai memiliki efek positif (Lindhiem, Kolko, \& Cheng, 2012). Salah satu dari intervensi psikologis adalah berupa pelatihan dukungan sosial. Pelatihan dukungan sosial dipilih karena berkaitan dengan berbagai keuntungan yang bisa didapatkan oleh para korban diantaranya meningkatkan kesehatan baik fisik maupun psikologis dan meningkatkan kebahagiaan (Cohen \& Shyme, 1985), harga diri, kepercayaan diri, dan efikasi diri (Nezlek dkk, dalam Ibarra-Rovillard \& Kuiper, 2011). Individu yang mendapatkan dukungan sosial percaya bahwa dirinya dicintai, dihargai, menjadi bagian dari komunitas sosial (Sarafino, 2002). Secara umum dukungan sosial memiliki korelasi positif dengan kesehatan mental (Barnett \& Gotlib dalam Tajali, Sobhi, \& Ganbaripanah, 2010).

Dukungan sosial didefinisikan sebagai serangkaian sumber yang disediakan oleh orang lain. Sumber yang dimaksud dapat berupa informasi yang bermanfaat hingga berbentuk barang. WHO (Cohen \& Shyme, 1985) mengungkapkan bahwa hubungan sosial yang sehat menjadi salah satu prediktor kesehatan.

Sebaliknya, minimnya dukungan sosial akan membawa serangkaian dampak atau risiko bagi individu yaitu distress psikologi khususnya kecemasan dan depresi (Heaney, Phillips, \& Carrol, 2010) serta menurunkan kebahagiaan (IbarraRovillard \& Kuiper, 2011).

Alasan lain diperlukannya pelatihan dukungan sosial bagi warga Huntara adalah ditemukannya fakta bahwa minimnya interaksi sosial yang terjadi di sana menjadi permasalahan sosial tersendiri di samping berbagai permasalahan fisik dan ekonomi. Disediakannya Huntara bagi korban tidak begitu saja menyelesaikan permasalahan mereka. Berbagai permasalahan fisik dialami akibat minimnya sarana dan prasarana yang tersedia di lokasi Huntara di antaranya ketersediaan air bersih. Selain itu, permasalahan ekonomi juga dialami mereka yang sebelum bencana bermata pencaharian sebagai petani dan peternak. Lokasi rumah yang terbatas dan tanpa halaman tidak memungkinkan mereka dapat memelihara ternaknya di lokasi Huntara. Meskipun rumah warga Huntara berdekatan satu sama lain, tetapi tidak cukup mampu untuk menumbuhkan semangat kebersamaan seperti ketika sebelum terjadi bencana yang telah terjalin dengan baik (wawancara, 5 Mei 2012). Kondisi ini merupakan permasalahan sosial tersendiri bagi mereka.

Setelah mereka bertempat tinggal di Huntara, aktivitas yang melibatkan kebersamaan tidak pernah lagi dijalankan. Selama 17 bulan mereka berada di Huntara belum ada aktivitas bersama yang rutin dilakukan. Sebagian warga lebih fokus pada keperluan pribadinya masing-masing. Sebagian memilih pulang ke desa asalnya dan membiarkan rumah huntaranya kosong, dan sebagian lainnya ada yang memilih bertempat tinggal di 
rumah sanak saudara (wawancara, 5 Mei 2012).

Hasil wawancara lain juga menyebutkan bahwa saat ini warga yang berada di Huntara tersebut terpisah dalam dua kelompok yang keduanya tidak saling bertegur sapa. Selain tidak lagi bertegur sapa, mereka juga saling mengembangkan sikap curiga (wawancara, 5 Mei 2012).

Warga korban lahar dingin sesungguhnya merindukan suasana kebersamaan. Mereka membutuhkan suasana tetap terjaganya kedekatan dengan orang-orang yang senasib pasca letusan Merapi yang mengakibatkan daerah mereka terkena banjir lahar dingin. Kegiatan-kegiatan seperti arisan, pengajian, dan posyandu yang memungkinkan mereka saling bertemu dan bertegur sapa dirasa dapat mengurangi beban akibat bencana yang dialami.

Masih minimnya dukungan sosial pada warga Huntara X menunjukkan bahwa kondisi ini membutuhkan penanganan. Mengembalikan dukungan sosial antar masyarakat seperti ketika sebelum terjadi bencana perlu dilakukan agar masyarakat mendapatkan serang-kaian manfaat positif dari dukungan sosial yang diberikan satu sama lain.

Penelitian ini dilakukan dengan memberikan pelatihan dukungan sosial. Harapan yang ingin dicapai dalam pelatihan ini adalah dapat mengembalikan dukungan sosial warga seperti sebelum terjadi bencana yang telah terjalin baik. Selanjutnya peningkatan dukungan sosial diharapkan efektif dalam membangun kemandirian dan optimisme para pengungsi tersebut. Dengan demikian dapat dirumuskan hipotesis bahwa pelatihan dukungan sosial dapat meingkatkan optimisme.

\section{METODE PENELITIAN}

\section{Subjek Penelitian}

Subjek penelitian ini adalah warga Huntara X. Studi awal menunjukkan bahwa subjek di lokasi tersebut memiliki risiko rendahnya optimisme dan kemandirian warga sesuai dengan kajian dalam penelitian ini.

Kriteria subjek dalam penelitian ini adalah mereka yang berusia antara 25 tahun sampai 55 tahun atau usia produktif, pendidikan minimal SMU, memiliki skor kemandirian dan optimisme yang rendah dan atau sedang. Dari 90 skala, diperoleh 68 subjek memiliki skor kemandirian dan optimisme rendah dan sedang. Selanjutnya dari 68 subjek tersebut diperoleh 10 subjek yang bersedia mengikuti pelatihan secara penuh (menandatangani form kesediaan). Berdasar usia, subjek berada pada rentang usia 33 tahun sampai dengan 49 tahun $(M=41,8)$. Berdasar jenis kelamin, 6 subjek adalah laki-laki dan 4 subjek adalah perempuan. Berdasar pekerjaan, mereka adalah petani, peternak, dan pengrajin emping singkong. Kesepuluh subjek mendapatkan pelatihan dukungan sosial secara bersama-sama dalam kelompok eksperimen. 


\section{Rancangan Penelitian}

Metode penelitian ini adalah kuasi eksperimen dengan pretest-posttest group design (tabel 1).

Tabel 1. Rancangan Eksperimen

\begin{tabular}{lccc}
\hline Kelompok & Prates & Perlakuan & Pascates \\
\hline $\begin{array}{l}\text { Kelompok } \\
\text { Eksperimen }\end{array}$ & Y1 & $\mathrm{X}$ & Y2 \\
\hline
\end{tabular}

Keterangan :

Y1 : skor skala optimisme dan kemandirian pada saat pre-test.

Y2 : skor skala optimisme dan kemandirian pada saat post test.

$X$ : perlakuan berupa pelatihan dukungan sosial

\section{Metode Pengumpulan Data}

Pengumpulan data dalam penelitian ini menggunakan skala optimisme dan skala kemandirian. Skala optimisme disusun oleh peneliti dengan menggunakan teori optimisme dari Seligman (2006). Aspek-aspek optimisme meliputi permanence, pervasiveness, dan personalization. Aitem skala tersebut berjumlah 24 aitem dengan koefisien korelasi aitem dengan aitem total $>0,3$ yang bergerak antara 0,361 sampai 0,624 serta memiliki koefisien reliabilitas alpha sebesar 0,807. Aitem-aitem dalam skala optimisme menggunakan model skala Likert yang dimodifikasi dengan 4 (empat) alternatif respon yaitu Sangat Sesuai (SS), Sesuai (S), Tidak Sesuai (TS), dan Sangat Tidak Sesuai (STS). Pemberian skor untuk respon terhadap aitem favorable adalah respon
Sangat Sesuai (SS) diberi skor 4, Sesuai (S) diberi skor 3, Tidak Sesuai (TS) diberi skor 2, dan Sangat Tidak Sesuai (STS) diberi skor 1, dan sebaliknya bagi aitem unfavorable. Arti dari nilai tersebut adalah semakin tinggi nilai maka semakin tinggi optimisme.

Alat ukur yang kedua adalah skala kemandirian. Skala tersebut merupakan modifikasi dari skala kemandirian yang disusun oleh Masrun dkk (1986) yang mencakup aspek-aspek kemandirian sebagai berikut: (1) Bebas; (2) Progresif dan ulet, (3) Inisiatif; (4) Pengendalian diri dalam atau internal locus of control; dan (5) Kemantapan diri meliputi self esteem dan self confidence. Skala kemandirian terdiri atas 29 aitem yang memiliki korelasi aitem dengan aitem total $>0,3$ dan bergerak antara 0,302 sampai 0,723 serta memiliki koefisien reliabilitas alpha sebesar 0,877. Skala kemandirian terdiri atas pernyataan favorable dan unfavorable. Butir-butir pernyataan disusun berdasarkan modifikasi dari skala Likert dengan menggunakan 4 (empat) pilihan isian yang terdiri atas "sangat sesuai", "sesuai", "tidak sesuai", "sangat tidak sesuai". Nilai jawaban berbobot satu (1) sampai dengan empat (4). Jawaban "sangat sesuai" pada pernyataan favorable diberi nilai 4, "sesuai" diberi nilai 3, "tidak sesuai" diberi nilai 2, dan "sangat tidak sesuai" diberi nilai 1. Pada pernyataan unfavorable maka nilai berlaku sebaliknya. 


\section{Prosedur Intervensi}

Intervensi dalam penelitian ini adalah pelatihan dukungan sosial yang disusun dengan empat aspek dukungan sosial berdasarkan teori House (Smet, 1994). Aspek-aspek tersebut adalah: (1) dukungan emosional, (2) dukungan penghargaan, (3) dukungan informasi, dan (4) dukungan instrumental. Materi program dukungan sosial disusun dalam empat sesi pelatihan sesuai dengan jumlah aspek dalam dukungan sosial.

Proses pelatihan dukungan sosial kepada subjek dilakukan sebanyak dua tahap, yaitu persiapan dan tahap pelaksanaan. Tahap persiapan meliputi pendekatan (perkenalan, rapport) kepada seluruh subjek yang memenuhi kriteria penelitian. Setelah pendekatan, kemudian calon subjek diberikan penjelasan penelitian, dan persetujuan keterlibatan (informed consent). Tahap pelaksanaan dilaksanakan selama dua hari pada Sabtu, 13 Oktober 2012 dan Selasa, 16 Oktober 2012. Metode yang digunakan adalah ceramah, diskusi, dan bermain peran.

Pelaksanaan pelatihan pada hari pertama subjek mendapatkan materi sesi 1 dan sesi 2. Pada hari kedua subjek mendapatkan materi sesi 3 dan sesi 4 (Ringkasan materi pelatihan dukungan sosial dapat dilihat pada tabel 2). Pada hari kedua, aktivitas pelatihan diakhiri dengan post test.

Tabel 2. Ringkasan Materi Pelatihan Dukungan Sosial

No MATERI

Sesi 1. Dukungan Emosional

1. 1.1. Empati - ikut merasakan apa yang dirasakan orang lain

1.2. Peduli pada diri sendiri dan orang lain

1.3. Penghargaan pada diri sendiri dan orang lain

Sesi 2. Dukungan Penghargaan

2. 2.1. Ungkapan positif

2.2. Dorongan untuk maju

2.3. Penguatan positif (gagasan dan perasaan individu) dan Penghargaan

Sesi 3. Dukungan Informasi

3. 2.1. Memberikan petunjuk dan saran

2.2. Memberikan umpan balik

Sesi 4. Dukungan Instrumental

4. 4.1. Membantu dengan hal yang nyata

4.2. Memberi hal yang baik dan berguna 


\section{Metode Analisis Data}

Pengujian hipotesis dalam penelitian ini dilakukan secara kuantitatif menggunakan uji beda untuk mengetahui perbedaan skor optimisme dan kemandirian sebelum dan sesudah perlakuan. Analisis data menggunakan teknik statistic non parametric wilcoxon.

Analisis tambahan dilakukan dengan teknik visual inspection (Barlow \& Hersen, 1984). Teknik visual inspection ini menampilkan grafik skor optimisme dan kemandirian antara sebelum diberikan perlakuan dan setelah diberikan perlakuan. Data yang diperoleh berdasarkan grafik visual inspection akan dievaluasi secara kualitatif sehingga diperoleh dinamika skor optimisme dan kemandirian subjek.

\section{HASIL PENELITIAN}

Uji wilcoxon test dengan data prates dan pascates pada skala optimisme menunjukkan skor $\mathrm{Z}=-0,357 ; \mathrm{p}=$ 0,721 ( $p>0.05$ ). Skor rata-rata pascates sebesar 67,60 sedangkan rata-rata prates sebesar 67,10. Hal ini menunjukkan bahwa tidak ada perbedaan optimisme antara sebelum dan sesudah mengikuti pelatihan dukungan sosial.

Uji wilcoxon test dengan data prates dan pascates pada skala kemandirian menunjukkan skor $\mathrm{Z}=$ 2,$449 ; p=0,014(p<0.05)$. Skor ratarata pascates sebesar 73,30 sedangkan rata-rata prates sebesar 67,10 . Hal ini menunjukkan bahwa ada perbedaan kemandirian yang signifikan antara sebelum dan sesudah mengikuti pelatihan dukungan sosial.

Hasil visual inspection masingmasing subjek pada skala optimisme dapat dilihat pada gambar 1 .

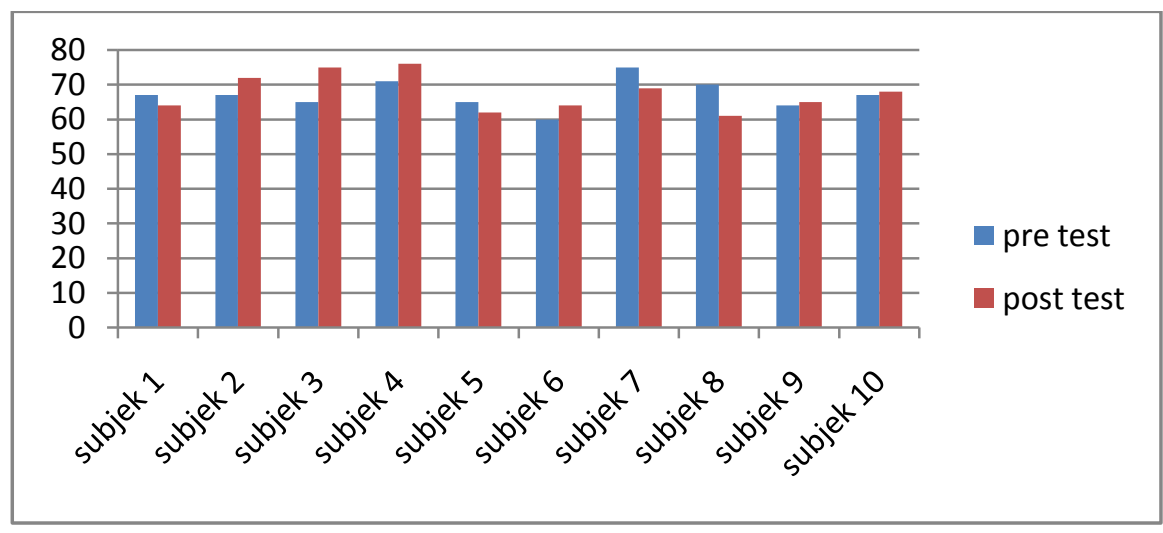

Gambar 1. Grafik Skor Prates dan Pascates Subjek Pada Skala Optimisme 
Hasil visual inspection masing- dapat dilihat pada gambar 2 masing subjek pada skala kemandirian

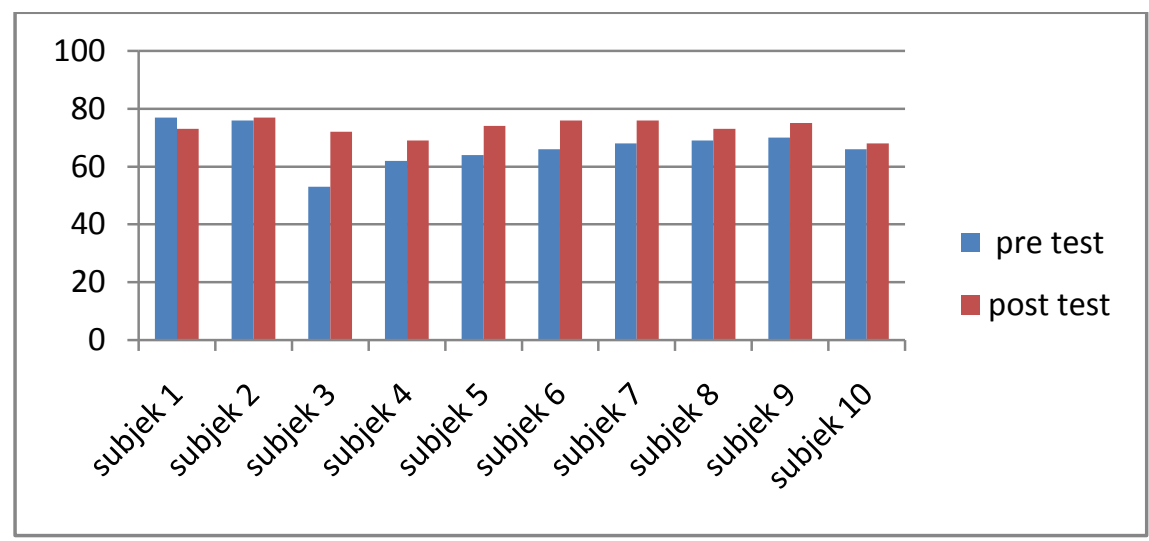

Gambar 2. Grafik Skor Pre Test - Post Test Subjek Pada Skala Kemandirian.

\section{PEMBAHASAN}

Hasil penelitian menunjukkan bahwa pelatihan dukungan sosial terbukti efektif untuk meningkatkan kemandirian. Guay (Guay dkk, 2006) mengungkapkan bahwa adanya dukungan yang diberikan lingkungan akan membuat seseorang merasa yakin, merasa dirinya berkompeten, dan mandiri.

Kemandirian, menurut Agnyal (Wolman, 1973), merupakan tendensi untuk mencapai sesuatu, mengatasi sesuatu, bertindak efektif terhadap lingkungannya, dan merencanakan serta mewujudkan harapan-harapannya. Hetherington (Spencer \& Kass, 1970) mengemukakan bahwa kemampuan untuk mengambil inisiatif, kemampuan mengatasi masalah, penuh ketekunan, serta memperoleh kepuasan dari usahanya sebagai perwujudan dari perilaku mandiri.
Serangkaian kemampuan tersebut pada penelitian ini dapat ditingkatkan dengan dukungan sosial.

Dukungan sosial dapat berdampak pada subjek dalam meningkatkan kemandirian karena perilaku individu (juga emosi dan kognisi) dipengaruhi oleh identitas (Alicke dkk, dalam Gaertner dkk, 2012). Identitas merupakan representasi dari keunikan/kekhasan individu, melibatkan internalisasi dan integrasi diri dengan sosial dan kelompok (Gaertner dkk, 2012).

Nilai-nilai budaya sangat mempengaruhi pertumbuhan identitas individu (Heine dkk, dalam Gaertner dkk, 2012). Identitas selanjutnya akan membentuk konsep diri individu. Konsep diri terdiri atas tiga bentuk dasar identitas yaitu individual self, relational self, dan collective self (Andersen \& Chen, dalam Gaertner dkk, 2012). Pada budaya 
kolektif, identitas yang dominan adalah relational self (Yuki, dalam Gaertner dkk, 2012). Relational self merupakan refleksi individu pada kedekatan interpersonal yang saling bertimbal balik dan saling membagi peran dengan individu yang memiliki relasi personal mendalam (Gaertner dkk, 2012).

Pada budaya kolektif yang menjadi ciri budaya negara Timur (Gaertner, Sedikides, Luke, O'Mara, Luzzini, Jackson, Cai, \& Wu, 2012), salah satunya Indonesia, nilai khas yang berkembang adalah kebersamaan (communality), keterhubungan (connectedness), importance of others yang bermakna individu lain seperti keluarga, teman, tetangga menempati porsi yang penting (De Vos, dalam Gaertner dkk) dan sikap yang saling kebergantungan yaitu fokus pada kepentingan orang lain dibanding diri/allocentric, keterhubungan, dan kolektif (Markus \& Kitayana, dalam Gaertner dkk, 2012).

Hasil penelitian selanjutnya menunjukkan bahwa pelatihan dukungan sosial tidak efektif dalam meningkatkan optimisme. Salah satu sebab dari tidak terbuktinya efektivitas suatu perlakuan dalam eksperimen dapat dilihat dari sisi validitasnya. Dalam penelitian eksperimen terdapat dua macam validitas, yaitu validitas internal dan validitas eksternal (Azwar, 2010). Pada penelitian ini hanya dituliskan ancaman terhadap validitas internal karena merupakan hal yang harus dicapai oleh setiap prosedur eksperimen sedangkan validitas eksternal lebih meru- pakan kesimpulan induktif yang tidak pernah dapat dipenuhi secara mutlak (Azwar, 2010).

Validitas internal pada suatu eksperimen dikatakan tinggi apabila perubahan yang terjadi pada variabel dependen benar-benar disebabkan oleh perlakuan yang diberikan dalam eksperimen, bukan disebabkan faktor kebetulan maupun disebabkan oleh faktor-faktor lain yang tidak relevan (Azwar, 2010).

Validitas internal yang tinggi dapat diperoleh dengan cara mengendalikan jalannya eksperimen sedemikian rupa sehingga pengaruh variabel independen yang akan diukur pengaruhnya terhadap variabel dependen tidak dicemari hal-hal lain yang tidak dikehendaki. Desain eksperimen yang tepat memungkinkan ancaman validitas internal menjadi minimal (Azwar, 2010). Bentuk-bentuk ancaman terhadap validitas internal menurut Azwar (2010) adalah (1) Histori, (2) Maturasi, (3) Testing, (4) Instrumentasi, (5) Regresi statistika, (6) Seleksi, (7) Mortalitas, dan (8) Interaksi berbagai faktor.

Berdasarkan beberapa sebab yang diungkapkan oleh Azwar (2010), hal yang diduga mengurangi validitas internal pada penelitian ini dan dapat berakibat pada tidak validnya hasil pengukuran adalah maturasi. Maturasi adalah proses perubahan yang terjadi pada subjek eksperimen yang terjadi seiring dengan berjalannya waktu. Maturasi biasanya terjadi ketika pelaksanaan eksperimen 
dilakukan dalam jangka waktu yang panjang. Maturasi bisa terjadi akibat kelelahan, bosan, lapar, atau bertambahnya usia. Perubahan ini dapat mempengaruhi performansi subjek dalam eksperimen baik ke arah yang positif maupun ke arah yang negatif.

Rangkaian proses pelatihan ini dilakukan dalam waktu 2 hari. Penyajian skala pascates dilakukan pada hari kedua setelah proses pelatihan selesai. Skala optimisme disajikan pada urutan kedua setelah skala kemandirian. Bosan dan kelelahan dapat terjadi dan mempengaruhi performa subjek ketika memberikan respons pada skala optimisme.

Hasil analisis visual inspection dari skala optimisme tampak bahwa 6 subjek mengalami peningkatan skor. Hasil analisis visual inspection dari skala kemandirian menunjukkan bahwa 9 subjek mengalami peningkatan skor. Hasil visual inspection ditampilkan untuk lebih detail melihat kemungkinan hasil yang cukup berarti. Hasil dianggap cukup bermakna dan dapat ditampilkan setelah dilakukan cross check dengan hasil evaluasi pada lembar evaluasi dan wawancara terhadap manfaat pelatihan dukungan sosial.

Hasil wawancara menunjukkan bahwa sebagian besar peserta merasa senang dan dapat merasakan manfaat dari keterampilan yang telah dilatihkan selama pelatihan dukungan sosial (Subjek 1, Subjek 4, Subjek 6, Subjek 7, Subjek 8, Subjek 10). Sebagian lain mengatakan bahwa pelatihan semacam ini sangat dibutuhkan secara berkala (Subjek 5). Subjek 2 mengatakan bahwa pelatihan ini mampu memberikan penyegaran dan mengingatkan kembali pentingnya kebersamaan antar sesama warga. Permasalahan yang dialami warga yakni kecemasan akan kepastian tempat tinggal dan serangkaian permasalahan yang menyertainya seringkali membuat mereka melupakan pentingnya kebersamaan. Permasalahan cenderung membuat mereka fokus pada dirinya sendiri sehingga pelatihan dukungan sosial diharapkan dapat mengingatkan kembali bahwa kebersamaan warga sangat penting.

Pelatihan dukungan sosial yang dikoordinasi secara baik diperlukan. Subjek 3 mengusulkan agar kegiatan bersama dilakukan kembali setelah sudah lama tidak dilaksanakan. Kegiatan tidak hanya terbatas pada pengajian dan arisan namun ada pemberdayaan berupa informasi-informasi yang bermanfaat bagi pengembangan diri. Subjek juga mengusulkan kemungkinan untuk bekerja sama dengan instansi pemerintah, seperti puskesmas, dinas kesehatan, maupun perguruan tinggi untuk memberikan pelatihan yang berguna bagi pengembangan masyarakat.

Selain merasa senang dengan adanya pelatihan dukungan sosial ini, subjek juga merasa bahwa apa yang didapat dalam pelatihan membuat mereka lebih bersemangat dan yakin dengan 
kehidupannya. Subjek juga merasa lebih percaya diri dalam menatap masa depan. Subjek 3 mengatakan bahwa sepertinya musibah yang dialami tampak berat namun ternyata ia bisa juga melewatinya. Subjek lainnya mengemukakan bahwa perasaan senasib sepenanggungan membuat mereka bertambah kuat dan merasa tidak sendirian.

Kelemahan-kelemahan yang menjadi keterbatasan penelitian ini adalah (1) jumlah subjek yang memenuhi kriteria dan bersedia mengikuti intervensi secara utuh sangat terbatas, (2) tidak ada kelompok kontrol sebagai pembanding sehingga hasil penelitian tidak dapat dibandingkan dengan kelompok yang tidak mendapat perlakuan, dan (3) tidak dilakukan pengukuran ulang setelah intervensi sehingga konsistensi keberhasilan intervensi kurang dapat dipastikan kekuatannya.

\section{SIMPULAN DAN SARAN}

\section{Simpulan}

Berdasarkan analisis data statistic dengan uji non parametric wilcoxon dapat disimpulkan bahwa (1) Pelatihan dukungan sosial tidak efektif meningkatkan optimisme pada korban lahar dingin Merapi Yogyakarta dan (2) Pelatihan dukungan sosial efektif meningkatkan kemandirian pada korban lahar dingin Merapi Yogyakarta. Berdasarkan analisis visual inspection yang telah digabungkan dengan data evaluasi dan wawancara disimpulkan bahwa terdapat pengaruh pelatihan dukungan sosial terhadap subjek peneli-tian. Pengaruh tersebut yaitu mengingat-kan kembali pentingnya kebersamaan antar sesama warga, menjadi lebih bersemangat dan merasa tidak sendirian, serta lebih percaya diri dalam menghadapi masa depan.

\section{Saran}

Ada beberapa saran yang perlu disampaikan. Pertama, untuk subjek Penelitian. Berdasarkan kesimpulan tersebut dapat disarankan kepada subjek untuk mengadopsi materi-materi yang disampaikan dalam pelatihan dukungan sosial sebagai usaha untuk meningkatkan kemandirian.

Kedua, untuk peneliti selanjutnya. Peneliti menyarankan (1) untuk melakukan replikasi penelitian dengan menggunakan modul pelatihan dukungan sosial sebagai bahan intervensi terhadap variabel bebas yang lain sehingga modul pelatihan tersebut dapat teruji validitasnya dalam merubah perilaku, (2) perlu adanya kelompok kontrol dan pengukuran setelah intervensi (follow up) perlu diberikan untuk melihat konsistensi keberhasilan intervensi, dan (3) subjek penelitian perlu ditambah untuk kepentingan generalisasi yang lebih luas.

Ketiga, untuk pihak-pihak yang memiliki program untuk membantu korban bencana Merapi (pemerintah, LSM, dan lain sebagainya). Bagi berbagai pihak yang memiliki program untuk 
membantu korban bencana Merapi, dapat memakai hasil penelitian ini sebagai salah satu referensi dalam memberikan intervensi untuk meningkatkan kemandirian.

\section{DAFTAR PUSTAKA}

Azwar, S. (2010). Metode Penelitian. Cetakan X. Yogyakarta: Pustaka Pelajar.

Barlow, D.H. \& Hersen, M. (1984). Single Case Experimental Designs: Strategies for Studying Behavior Change. Second Edition. New York: Pergamon Press.

Carver, C.S. \& Scheier, M.F. (2001). Optimism, Pessimism, and Self Regulation. dalam Chang, E.C (ed), Optimism \& Pessimism: Implications for Theory, Research, and Practice (hal. 31-51). Washington: American Psychological Association

Cohen, S., \& Syme, L. (1985). Social Support and Health. Florida: Academic Press.

Gaertner, L., Sedikides, C., Luke, M., O'Mara, E.M., Luzzini, J., Jackson, L.E., Cai, H., \& Wu, Q. (2012). A Motivational Hierarchy Within: Primacy Of The Individual Self, Relational Self, or Collective Self?
Journal of Experimental Social Psychology, 48, 997-1013.

Gillham, J.E., Shatte, A.J., Reivich, K.J., \& Seligman, M.E.P. (2001). Optimism, Pessimism, an Explanatory Style. dalam Chang, E.C (ed), Optimism \& Pessimism: Implications for Theory, Research, and Practice (hal. 53-75). Washington: American Psychological Association.

Guay, F., Ratelle, C.F., Senecal, C., Larose, S., \& Deschenes, A. (2006). Distinguishing Developmental From Chronic Career Indecision: Self Efficacy, Autonomy, and Social Support. Journal of Career Assessment, 14, 235-251.

Heaney, j.L.J., Phillips, A.C., \& Carrol, D. (2010). Ageing, Depression, Anxiety, Social Support and The Diurnal Rhythm and Awakening Response of Salivary Cortisol. International Journal of Psychophisiology, 78, 201-208.

Ibarra-Rovillard, M.S.,\& Kuiper, N.A. (2011). Social Support and Social Negativity Findings in Depression: Perceived Responsiveness to Basic Psychological Needs. Clinical Psychology Review, 31, 342-352.

Lindhiem, O., Kolko, D.J., \& Cheng, Y. (2012). Predicting Psychotheraphy 
Benefit: a Probabilistic and Individualized Approach. Behavior Therapy, 43, 381-392.

Masrun, Martono, Haryanto, F.R. Purbo Hardjito, Muhana, S.U., Anuryati, B., Aritonang, L., dan Soetjipto, H. (1986). Studi Mengenai Kemandirian pada Penduduk di Tiga Suku Bangsa (Jawa, Batak, Bugis). Laporan Penelitian. Kantor Menteri Negara Kependudukan dan Lingkungan Hidup dan Fakultas Psikologi Universitas Gadjah Mada.

Seligman, M.E.P. (2006). Learned Optimism: How to Change Your Mind and Your Life. New York: Vintage Books.

Sheikholeslami, R., \& Arab-Moghaddam, N. (2010). Relations of Autonomy and Adjusment in Iranian College Students: a Cross-Culture Study of Self-Determination Theory. Procedia Social and Behavioral Sciences, 5, 1831-1835.

Smet, B. (1994). Psikologi Kesehatan. Jakarta: Grasindo.

Spencer, T.D., \& Kass, N. (1976). Perspective in Child Psychology. New York: McGraw-Hill Book Company.
Tajalli, P., Sobhi, A., \& Ganbaripanah, A. (2010). The Relationship Between Daily Hassles and Social Support on Mental Health of University Students. Procedia Social and Behavioral Sciences 5, 99-103.

Wolman, B.B. (1973). Dictionary of Behavioral Science. New York: Van Nostrand Reinhold Company.

Internet

Antaranews.com. (2011). Menanti Habisnya Material Erupsi Merapi. Diunduh pada 2 Mei 2012, dari http://www.antaranews.com/print/2 42509/.

Jalin Merapi.net. (2011). Perkembangan Terkini Data Kabupaten Magelang per 19 Januari 2011. Diunduh pada 2 Mei 2012, dari http://jalinmerapi.net/baca/12154/p erkembangan-terkini-datakabupaten magelang-per-19-januari2011.html.

Kompas.com. (2011). Lahar Dingin Merapi Masih Mengancam. Diunduh pada 2 Mei 2012 dari http://regional.kompas.com/read/20 11/11/01/14563834/Lahar.Dingin. Merapi.Masih.Mengancam. 
Bappenas-BNPB. 2011. Rencana Aksi Rehabilitasi dan Rekonstruksi Wilayah Pascabencana Erupsi Gunung Merapi di Provinsi DIYogyakarta dan Provinsi Jawa Tengah Tahun 2011-2013.
Diunduh pada 2 Mei 2012 dari http://pusdiklat.bnpb.go.id/home/D ownloads/Peraturan \%20PerundangUndangan $\%$ 20terkait $\%$ 20RR/RENA KSI\%20MERAPI\%2016\%20Juli\%20 2011.pdf. 